\title{
HAZARDS AND RISKS TO CONSUMERS' HEALTH CAUSED BY POPSICLES ON SALVADOR BEACHES - BAHIA STATE
}

Renata Oliveira dos Santos Menezes', Ryzia de Cássia Vieira Cardoso², Alaise Gil Guimarães ${ }^{3}$

Corresponding author: Renata Oliveira dos Santos Menezes - renata.oliveira.nut@gmail.com

'MSc in Food Science. Professor at Estácio da Bahia University Center, Salvador, Bahia, Brazil.

${ }^{2} \mathrm{PhD}$ in Food Science and Technology. Professor at the Federal University of Bahia, Salvador, Bahia, Brazil.

${ }^{3} \mathrm{PhD}$ in Food Microbiology. Professor at the Federal University of Bahia, Salvador, Bahia, Brazil.

\begin{abstract}
Introduction: Beaches are a place for interaction and leisure, as well as a scenery for the provision of services, including the street food trade. In this segment, different workers with different type of foods are included, especially the popsicles. Methods: This study aimed to characterize microbiologically the popsicles commercialized on the beaches of Salvador, Bahia State. A cross-sectional study was carried out on 13 beaches, with the application of semistructured questionnaires to 33 vendors to characterize microbiologically the popsicles sold on the beaches of Salvador, Bahia State, and the collecting of 198 samples, which were submitted to analysis: counting of Psychrotrophic microorganisms and coagulase-positive staphylococci, estimation of the Most Likely Number of total and thermolerant Coliforms/Escherichia coli and Salmonella spp research. Results: The results showed that in the microbiological profile, most of the samples were in compliance with the standards. However, $34.3 \%$ (68) of non-compliance were recorded, including contamination by the various microorganisms studied, except for Salmonella spp., which was not identified. Conclusion: The study identified risks to the costumer's health, given the contamination in the products, for both groups of sellers.
\end{abstract}

Keywords: Cross-sectional studies, Escherichia coli, Salmonella, food safety. 
In Brazil, beaches are a place of coexistence and leisure, also important in the generation of work and income, mainly as a survival strategy for the poorest populations. On the other hand, although it presents contributions to the urban social balance, the beach economy has not been constituted as the object of public policies and studies, what makes the services to be rendered, to a large extent, informally developed, in the margin of regulation systems'.

In this scenario, the street food trade deserves to be highlighted, since, besides maintaining the local food culture and attending to the beach-goers needs, it constitutes an opportunity of work for socially excluded groups ${ }^{2}$.

In Salvador - Bahia State, street food sale on the beach is a tradition that has been perpetuated by the social and economic characteristics of the city. Thus, considering the high level of unemployment in the city, the activity is an attraction; A wide range of foods, including typical snacks of African cuisine, fruits in natura, fish with different preparations, skewers of cheese and beef, homemade salty snacks and sweets, nuts and peanuts, quail eggs, popsicles, among others.

It is added to the description that many consumers opt for street food because it is cheap and easily accessible ${ }^{3}$. This option, however, assumes risks related to the health of sold products, since studies in this field have evidenced the microbiological contamination of several foods that appear in the preference of the population and the tourists, including in the city of Salvador ${ }^{4,5}$.

According to epidemiological surveys, the association of the consumption of popsicles with outbreaks of food-borne diseases has been verified, emphasizing the importance of the composition aspects of the products and the technological stage of the manufacturing sites ${ }^{6}$. Among the studies conducted in the microbolological perspective, many have portrayed the presence of deteriorating and pathogenic microorganisms, especially the contamination by Escherichia coli, Staphylococcus aureus, Salmonella spp and psychrotrophic microorganisms $s^{6,7,8,9}$.
In Salvador, the manufacture of popsicles on artisanal scale is also notable, with subsequent sales in different parts of the city, including beaches, with the participation of smaller sellers ${ }^{10}$. Thus, this study aimed to characterize microbiologically the popsicles sold on the beaches of Salvador, Bahia State.

\section{METHODS}

This is a cross-sectional, descriptive and exploratory study, conducted from 2009 to 2010 along the entire coastline of the city of Salvador, with the inclusion of 13 identified beaches according to the delimitation and geographical denomination already established in the city, where the collection sites are constituted and characterized by the intense commerce and great flow of people, where the sellers and the consumers were concentrated.

For the composition of the sample, it was followed a model of itinerant sampling 11 , together with sellers of popsicles, with approach and interview of 13 sellers under 18 years old and 20 adults, followed by the acquisition of a set of 198 samples.

In order to obtain samples that allowed to evaluate the microbiological profile of foods and considering the number of vendors referred to, six samples per vendor were sold, packaged and unpackaged, three of which were milk based and three were fruit based. In total, 78 samples sold by children and teenagers and 120 samples sold by adult sellers were gathered/obtained.

The samples were collected aseptically, packed in sterile Nasco $\AA$ plastic bags, placed in isothermal boxes containing recyclable ice and transported to the Food Microbiology Research Laboratory of the Pharmacy College/UFBA, being kept under cooling until the moment of analysis, in a break of no more than four hours.

The microbiological analyzes included: counting 
of psychrotrophic microorganisms, Most Probable Number (MPN) of total and thermotolerant coliforms/Escherichia coli, coagulase-positive staphylococci and Salmonella spp research. The procedures followed the techniques established by Silva et $\mathrm{al}^{12}$.

The results were compared to the standards presented by the Collegiate Board Resolution 12/2001, of the National Agency of Sanitary Surveillance (ANVISA, Ministry of Health), the Food Group - popsicles, "A" category $^{13}$, with the exception of the enumeration of psychrotrophic microorganisms. In this case, considering that the psychrotrophic microorganisms are a subgroup of the mesophiles, it was used as a reference the $\mathrm{FAO} / \mathrm{WHO}$ specifications for total counts of mesophilic aerobes in foods, specifically for the group of frozen mixtures ${ }^{14}$.

The data referring to the forms and the microbiological analysis were tabulated and composed a database using the statistical package SPSS version 13.0. The results were statistically treated by descriptive analysis, while for the ones related to the microbiological analysis the values were converted to logarithmic scale and analysis were carried out by a comparison test of means, Student's t test, to verify differences between products sold by adults and by minors, as well as to verify the variation in counting between milk-based products and fruitbased products. In addition, tests were conducted for differences in proportions Z. In both cases, it was adopted the level 0.05 of probability.

\section{ETHICAL CONSIDERATIONS}

In order to comply with ethical principles in health research with human beings, the presence of children and adolescents among the individuals interviewed was also highlighted. The project was approved by the Ethics Committee of the Climério de Oliveira Maternity (Opinion 090/2008) and also by the Municipal Council for the Rights of the Child and Adolescent (198th Ordinary Assembly, June 18, 2008).

\section{RESULTS}

The results of the microbiological analysis of the popsicles samples collected on the beaches of Salvador are shown in Table 1, and the discussion is presented by the group or microorganism analysis, as follows:

\section{- Psychrotrophic microorganisms}

The analyzed popsicles samples presented average results in accordance with the FAO/WHO limit of $4.3 \log$ of CFU/g 14, in samples sold by underage vendors and adults.

Among the fruit-based popsicles samples, it was observed that there was a significant difference between the averages of counting of psychrotrophs registered for children and adults $(p=0.03)$. On the other hand, the higher count of these microorganisms was observed in a sample of an adult salesman.

For the analyzed sample, only $4 \%$ exceeded the values recommended by $\mathrm{FAO} / \mathrm{WHO}(1989)^{14}$.

- Total, thermotolerant and E. coli coliforms

As shown in Table 1, it was possible to identify the presence of total coliforms in the samples of both categories of products, although there is no legal standard for this group of microorganisms. At the same time, it was found that in the milk- based category the average values were always higher than those obtained for fruit products, although these results did not reach a significant difference. 
Table 1. Characterization of popsicles samples for microbial contamination (log of Colony Forming Units (CFU)/g or Most Likely Number (MLN)/g or Presence).

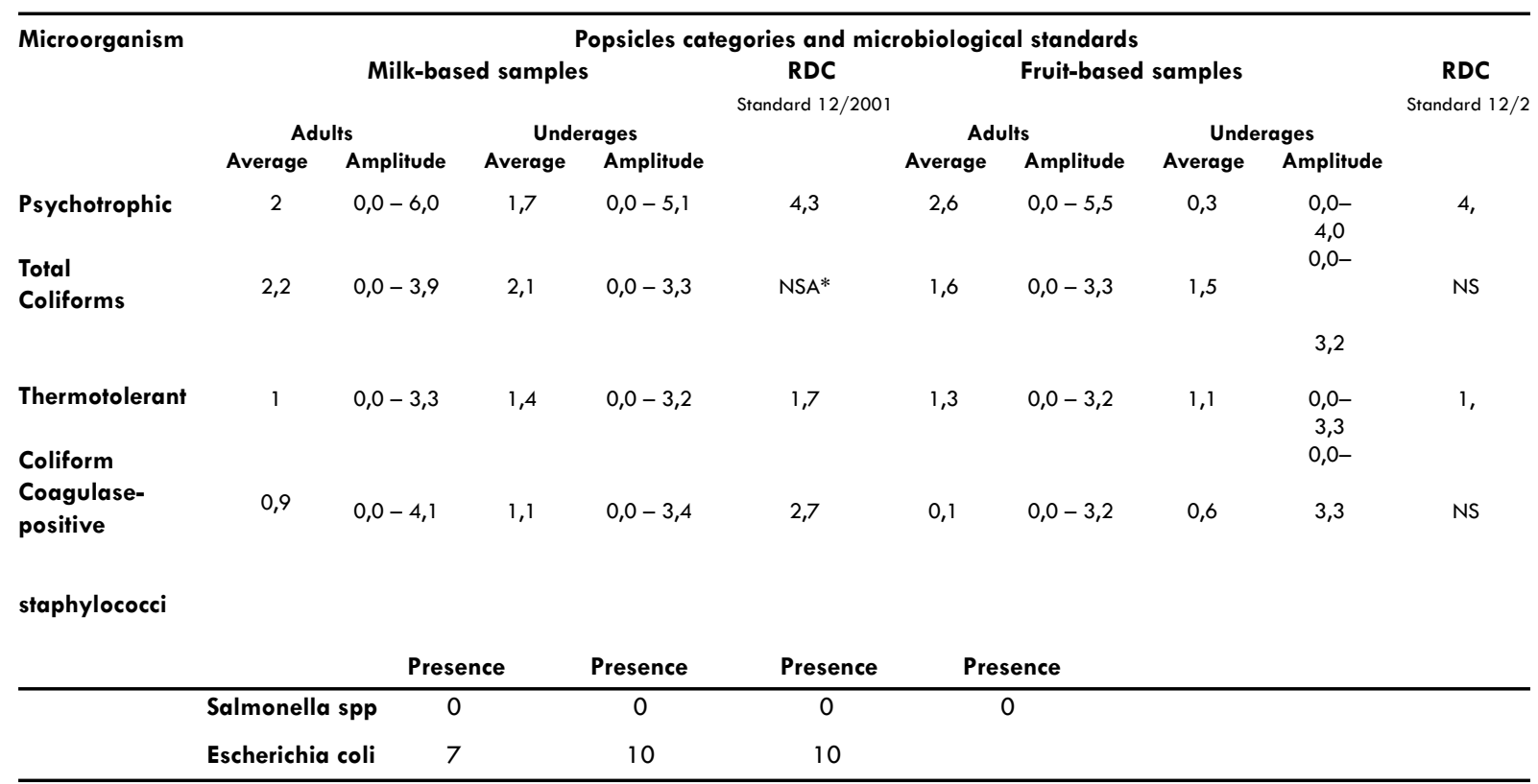

As for thermotolerant coliforms, most of the samples showed compliance with the legislation. For the set of analyzed samples in Salvador - BA, 8.08\% ${ }^{8}$ of the milk-based samples and $7.07 \%{ }^{7}$ of the fruit-based samples were classified as unfit for consumption because they exceed the microbiological limit established. There was no difference in the averages comparison between the adult and underage groups.

However, the confirmation of the presence of highfrequency of $E$. coli in both milk-based and fruitbased popsicles in both groups of vendors was a matter of concern.

\section{- Coagulase-positive staphylococci}

The average values recorded for coagulase-positive staphylococci in the analyzed popsicles were lower than those recommended by the legislation for this food category (2.7 log CFU / g). However, there was a correspondingly higher incidence of this microorganism in the milk-based popsicles samples sold by both adults and children, reaching almost a quarter of the milk-based samples obtained.

In this case, given that some of the popsicles were obtained in the packaged form, it is presumed that the contamination came from production establishments, where the insufficient application of Good Practices and the lack of heat treatment resulted in products already contaminated. For the sample set $5.05 \%{ }^{10}$ were considered nonconforming.

- Salmonella spp

Salmonella spp was absent in the analyzed samples.

- Evaluation of the global condition of conformity of samples.

The results for compliance for all samples are shown in Table 2.

As it can be seen, milk-based samples had the highest incidence of non- compliant products when compared to fruit-based popsicles.

For the groups of sellers, the highest incidence of non-conforming samples was observed for the group of children and adolescents in both categories of products and also in the general statement, although this last proportion of non-conformity did not result in a significant difference in the comparison between these two groups $(p=0.08)$. 
Table 2. Distribution (\%) of samples for compliance, observing product categories and vendor groups.

\begin{tabular}{|c|c|c|c|c|c|c|}
\hline & \multicolumn{2}{|c|}{ Milk-based samples } & \multicolumn{2}{|c|}{ Fruit-based samples } & \multirow{2}{*}{$\begin{array}{c}\text { Total in } \\
\text { conformity }\end{array}$} & \multirow{2}{*}{$\begin{array}{c}\text { Total } \\
\text { nonconform } \\
\text { ng }\end{array}$} \\
\hline & In conformity & Nonconformity & In conformity & Nonconformity & & \\
\hline Seller & n (\%) & n (\%) & n (\%) & n (\%) & n (\%) & n (\%) \\
\hline Underage & $18(46.2)$ & $21(53.8)$ & $26(66.7)$ & $13(33.3)$ & $44(56.4)$ & $34(43.6)$ \\
\hline Adult & $43(71.7)$ & $17(28.3)$ & 43 (71.7) & $17(28.3)$ & $86(71.6)$ & $34(28.4)$ \\
\hline Total & $61(61.7)$ & $38(38.3)$ & $69(69.7)$ & $30(30.3)$ & $130(65.7)$ & $68(34.3)$ \\
\hline
\end{tabular}

\section{DISCUSSION}

\section{- Psychrotrophic microorganisms}

Regarding the findings on psychrotrophic microorganisms, the result can be explained by the fact that popsicles, are almost always acquired at points of sale - establishments of artisanal production, and taken directly to commercialization on the beaches of Salvador and elsewhere, being exposed for a long time to higher temperatures, which would alter the sensorial characteristics of this food, due to the fusion of the product, leading to rejection by consumers.

According to Silva et al.12, psychrotrophs are microorganisms that grow in the food under refrigeration $\left(0-7^{\circ} \mathrm{C} / 32-44,6^{\circ} \mathrm{F}\right)$, even though they still are present in temperatures above $20^{\circ} \mathrm{C}\left(68^{\circ} \mathrm{F}\right)$.

They are further defined by their ability to produce visible growth at $7+1^{\circ} \mathrm{C}\left(44,6+33,8^{\circ} \mathrm{F}\right)$, in the period of 7 to 10 days, regardless of their optimal temperature.

It is considered that, since adult vendors were carrying popsicles boxes with greater capacity and spending more time on the beach, there was a greater opportunity for exposures and further contamination of the product during the trade.

Children and adolescents, because of their short physical sizes, sold small volumes, which reduced the chances of contamination, which may explain the higher count of psychrotrophs for adult sellers.

Although there is no standard for these microorganisms in the current Brazilian legislation, these data reflect precariousness in the hygienic quality of popsicles, since most pathogenic microorganisms are mesophilic
- including psychrotrophic ones, and when they are present in high amounts, they provide an idea about the state of conservation of a product ${ }^{15}$. According to Silva et $\mathrm{al}^{12}$ psychrotrophic microorganisms comprise a subgroup of mesophiles because they do not die at room temperature, as do psychrophiles which grow exclusively under refrigeration; instead, psychrotrophs grow best at mesophilic standard temperatures.

As for thermotolerant coliforms, most of the samples showed compliance with the legislation, which is close to a result presented by Queiroz et al.9, when analyzing samples of tapioca ice cream, in Fortaleza - Ceara State.

The presence of $E$. coli at high frequency in both milk-based and fruit-based popsicles and in both groups of vendors was similar to those reported by Ferrari et al. 8 and, in higher percentages than those reported by Diogo et al.6, in studies conducted with ice cream analysis, at Paraná State, in the cities of Londrina and Ponta Grossa, respectively. Thus, the evidence of risks of other pathogenic microorganisms of enteric origin is highlighted, since E. coli indicates recent contamination, which also signalizes the viability of other organisms, including parasites, bacteria and viruses ${ }^{12}$.

As for coagulase-positive staphylococci, the higher incidence of this microorganism in the milk-based popsicles samples, commercialized by both adults and children, reaching almost a quarter of the milkbased samples obtained, represents important information since the low temperature of the popsicles do not indicate microbiological safety, even because microbial contamination can occur both by the use of poor raw material and by contact 
with utensils and food handler?

Compared to other studies conducted on the subject, the results obtained in Salvador are similar to the study described by Queiroz et $\mathrm{al}^{9}$, who reported the presence of coagulase-positive staphylococci at values below the legal limit. However, different results were found by Warke et al ${ }^{17}$, who analyzed ice creams in Mumbai, India, and by Diogo et $\mathrm{al}^{6}$, who evaluated ice creams in Ponta Grossa-PR. According to these authors, $100 \%$ and $66.7 \%$ of the popsicles samples, respectively, were in unsatisfactory hygienic conditions.

The absence of Salmonella spp in the analyzed samples complies with the current legislation and resembles to the found by Warke et $\mathrm{al}^{17}$, who did not detect Salmonella spp in any of the 30 ice cream samples analyzed in Mumbai, India, and by Diogo et $\mathrm{al}^{6}$, in his study in Brazil. On the other hand, there is a divergence in reference to the study by Queiroz et $\mathrm{al}^{9}$, which evidenced the presence of Salmonella spp in $75 \%$ of the analyzed samples. El-Sharef et $\mathrm{al}^{18}$ also identified the microorganism in $8 \%$ of the ice-cream samples analyzed in Tripoli, Libya.

In this perspective, it should be noted that Salmonella spp is characterized by low competition capacity in the food matrices and, therefore, are often found in low numbers, and there is also difficulty in recovering the microorganism in the classic laboratory techniques ${ }^{16}$.

Thus, although there was no identification of this microorganism, the evidence of total and thermotolerant coliforms, as well as coagulasepositive staphylococci, confirms the production of popsicles outside the microbiological standards.

The milk-based samples showed the highest percentage of nonconformity, which may be related to the specific composition of the first ones, since the milk, besides comprising a food matrix very rich in nutrients and susceptible to contamination from the time of its production until the later processing processes, may confer protection to the microorganisms due to the presence of glycerol, lactose, amino acids, protein salts and seroproteins, which differs markedly from the solids present in the fruit-based popsicles ${ }^{19}$.
Noting that the total of non-conformities reached almost a third of the sample set, it is worth to note the concern with the public health and the microbiological quality of the popsicles sold on the beaches. Thus, questions are raised, both in the scope of workers and their precarious working conditions, as well as in regard to the origin and hygienic-sanitary conditions of the manufacturing sites of the products.

This confirms the need for measures that can promote the quality of commercialized food and protect the consumer's health.

\section{CONCLUSION}

Considering the objectives established in the study and the obtained results, it is concluded that: Most of the popsicles samples analyzed were within the standards. However, almost one third of non-compliant samples were registered, including contamination by the various microorganisms researched, with the exception of Salmonella spp, for which there was no identification. Among the categories of analyzed products, the frequency of non-compliance was higher for milk-based popsicles.

Thus, the need to keep products at a controlled temperature is emphasized, as well as to guide sellers to avoid direct food contact with the hands, limiting the access to the food by microorganisms. In this way, it will be possible to avoid foodborne diseases from popsicles, contributing to the maintenance of consumer's health on the beaches of Salvador, Bahia.

\section{AUTHOR CONTRIBUTIONS}

Menezes ROS collected and analyzed the data and wrote the manuscript under the supervision of Guimarães AG and Cardoso RCV.

\section{COMPETING INTERESTS}

No financial, legal or political competing interests with third parties (government, commercial, private foundation, etc.) were disclosed for any aspect of the submitted work (including but not limited to grants, data monitoring board, study design, manuscript preparation, statistical analysis, etc.). 


\section{REFERENCES}

1. Souza RV, Lage V. A economia da Praia [Internet]. 2008 [Cited 28 Jan 2001]. Available from: http://201.2.114.147/bds/BDS.nsf/ C6A6CAA7CA536B60832574BA004548A2/\$File/ NT00038CBE.pdf. Portuguese.

2. Vidal JPO. Comida de rua e segurança de alimentos na orla marítima de Salvador-BA: Um estudo na perspectiva do trabalho infantil [dissertation]. Salvador-Bahia: Nutrition School. University Federal of Bahia; 2011 . Portuguese.

3. Lopes $A C$ et al. Vendedores ambulante alimentícios em Porto Velho-RO. Porto Velho, 2009. Monography (Biological Science Master's) - UNIRON - Faculdade Interamericana de Porto Velho. Portuguese.

4. Cardoso RCV, Santos SMC, Silva EO. Comida de rua e intervenção: estratégias e propostas para o mundo em desenvolvimento. Ciência \& Saúde Coletiva. 2009; 14(4):1215-1224. Portuguese.

5. Meneses RB. O comércio de queijo de coalho na orla marítima de Salvador-BA: O trabalho infantil, a rede de fornecedores e a segurança de alimentos [dissertation]. Salvador-Ba: Farmácia. Universidade Federal da Bahia; 2010. Portuguese.

6. Diogo GT, Aguiar GM, Tolentino MC, Buffara D, Pileggi M. Avaliação microbiológica de sorvetes comercializados na cidade de Ponta Grossa-PR e da água usada na limpeza das colheres utilizadas para servi-los. Biological and Health Sciences. 2002;8(1): 23-32; 2002. doi: 10.5212/ publicatio\%20uepg.v8i1.272. Portuguese.

7. Hoffman F et al. Qualidade higiênico - sanitária de sorvetes comercializados na cidade de São José do Rio Preto - SP Brasil. Boletim do CEPPA. 1995;13(2). doi: 10.5380/ cep.v13i2.14163. Portuguese.

8. Ferrari RG, Winkler SM, Oliveira TCRM. Avaliação microbiológica de alimentos isentos de registro pelo Ministério da Saúde. Semina: Ciências Agrárias, Londrina. 2007;28(2):241-250. Portuguese.

9. Queiroz HGS, Neta NAS, Pinto RS, Rodrigues MCP, Costa JMC. Avaliação da qualidade físico-química e microbiológica de sorvetes tipo tapioca. Revista Ciência Agronômica. 2009;40(1):60-65. Portuguese.

10. Cardoso RCV, Pimentel SS, Moreira LN, Santana CS, Cerqueira SC. Comida de rua: desvendando o mundo do trabalho e a contribuição social e econômica da atividade em Salvador-BA. Conjuntura e Planejamento, Salvador. 2005; 137:45-51. Portuguese.

11. Garin B, Aidara A, Spiegel A, Arrive P, Bastaraud $A$, Cartel JL et al. Multicenter study of street foods in 13 towns on four continents by the food and environmental network of Pasteur and associated institutes. J. Food Prot. 2002;65(1):146-52

12. Silva $\mathrm{N}$ et al. Manual de métodos de análise microbiológica de alimentos. 3 ed. São Paulo: Varela; 2007. Portuguese.

13. Brasil. Agência Nacional de Vigilância Sanitária ANVISA. Resolução da Diretoria Colegiada da Agência Nacional de Vigilância Sanitária RDC n. 12 de 2 de janeiro de 2001. Aprova o regulamento técnico sobre padrões microbiológicos para alimentos. Diário Oficial da República Federativa do Brasil, Brasília. DF. 2001. Portuguese.

14. Morton RD. Aerobic plate count. In: SILVA, N. da et al, Manual de Análises Microbiológicas de Alimentos. 3 ed. Varela. São Paulo; 2001. Portuguese.

15. Franco BDGM, Landgraf M. Microbiologia dos alimentos. 3 ed. São Paulo: Ateneu; 2005. Portuguese.

16. Okura $M H$, Oliveira $A B$, Pacheco $C R$, Carvalho MO, Lyra OS, Silva MLV et al. Avaliação da qualidade higiênico-sanitária de sorvetes, produzidos artesanalmente em Uberaba, MG. Food Hygiene. 2007;21 (154):72-75. Portuguese.

17. Warke R, Kamat A, Kamat M, Thomas P. Incidence of pathogenic psychrotrophs in ice creams sold in some retail outlets in Mumbai, India. Food Control. 2000;1 1:77-83. doi: 10.1016/S0956-7135(99)00027-4

18. El-Sharef $\mathrm{N}$ et al. Bacteriological quality of ice cream in Tripoli-Libya. Food Control. 2006;17:637-641

19. Carvalho EP, Abreu LR, Carvalho MC. Estudo de alguns aspectos microbiológicos em sorvetes não pasteurizados. Revista do Instituto de Laticínios "Cândido Tostes". 1995;50(291):43-49. Portuguese. 